\title{
Religious Experience as a Model for Emotional Experience in Theatre
}

\section{David V. Mason}

\section{Introduction}

In 2004 I attended a college production of a period play involving swords. ${ }^{1}$ In a climax building to the sigh of intermission, two characters took up arms against each other and, after a series of lunges, feints, and parries, one of them dealt a deadly thrust and the other followed with a quick stage death. Before the tension of the moment dissipated, however, the triumphant character bent to the stage corpse of his theatrical foe, placed a finger in the stage wound, and with a dramatic flourish jammed the befouled finger into his own mouth. Immediately, a sound rose like a signal to the house lights and the obligatory fifteen-minute break - a signal not from the stage but from a cluster of undergraduate students seated together close to the stage and center, who in perfect unison and stunning phonetic agreement said, "Eww!"

From the standpoint of any one of the historical understandings of theatrical mimesis, this " $E w w$ !-Effect" is a problem. It is one thing to acknowledge that theatrical activity inevitably imitates things outside the space and time of the theatre. It is something of a different order to confront the evidence that theatrical activity can take on a real, living life of its own, effectively existing as an ontological reality in the experience of the audience. Perhaps a degree of verisimilitude in theatre sometimes fools our conscious thoughts into a state of mistake, but in this case, the stage grotesquerie did not even include fake blood.

Reasoning from this one case, a production's naturalist aims, the psychological authenticity of its actors, and the realism of its set apparently have little to do with the $E w w$ !-Effect. Whatever the degree of realistic illusion intended by a production, the trappings of the theatre experience, from paid-parking to poorly upholstered seats to velour curtains, impose on an audience an uninterrupted discourse of fabrication. Not only might we cringe at blood-sucking on a stage, but we might also weep at Astyanax's death, grit our teeth at Stanley's abuse of Stella, and laugh at Bottom's disfigurement, as though all these things really happen while we watch. The philosophical term paradox of fiction denotes the problem of reacting to stories - as presented in novels, cinema, painting, etc. — as though to immediately real events. The theatrical variation on this paradox is that staged action can affect

David V. Mason is Assistant Professor of Theatre at Rhodes College. His work on Sanskrit drama and religious theatre in India has appeared in Theatre Research International, New Literary History, and previously in the Journal of Dramatic Theory and Criticism. His book Theatre Is Religion is forthcoming. 
us as though it is not pretense, even while it demonstrates its pretense. Cort Webb, our college classmate, is never dead and bleeding on stage, and while the presence of his familiar, not-character body makes the pretense explicit, while we know in a very conscious way that he's neither dead nor bleeding, we nevertheless see Brad Bergeron eat his blood, which, momentarily, like, grosses us out.

In The Varieties of Religious Experience, William James includes the anecdote of one of the "keenest intellects" of his acquaintance, which reads, in part:

On the previous night I had had, after getting into bed at my rooms in College, a vivid tactile hallucination of being grasped by the arm, which made me get up and search the room for an intruder; but the sense of presence so called came on the next night. After I had got into bed and blown out the candle, I lay awake awhile thinking on the previous night's experience, when suddenly I felt something come into the room and stay close to my bed. It remained only a minute or two. I did not recognize it by any ordinary sense, and yet there was a horribly unpleasant 'sensation' connected with it. ${ }^{2}$

It is hard not to note certain compelling similarities between the experience of James's acquaintance and the Eww!-Effect. In both cases the subjects suffer a physical experience or reaction, and in both cases that reaction is predicated on a stimulus which appears in all respects to be imaginary. That is, both experiences are of the type which art theory has considered paradoxical. As though throwing their arms in the air when confronted by a man with a banana, the subjects' physical/ emotional response overlooks the actual physical stimulus in favor of seeing and reacting according to a constructed, or imagined, stimulus. The kinds of experiences aesthetics has dubbed paradox of fiction, religious studies seems to know only as religious experience. ${ }^{3}$

James points out the essential perplexity of religious experience. Because their nature is not communicated or validated through sense content, he notes, following Kant, terms like god, soul, and immortality have no real significance. "Yet strangely enough," writes James, "they have a definite meaning for our practice. We can act $a$ s if there were a God; feel as if we were free; consider Nature as if she were full of special designs; lay plans as if we were to be immortal." ${ }^{4}$ In other words, the religious person acts (and reacts) as though things were much different than all the evidence suggests. In fact, a dogged disregard for the divide between the empirical world and the unverifiable seems to characterize religious experience. The experience of theatre can be much the same, as we act or react, like the undergraduates at The Illusion, not because of our senses, but in spite of them.

The same mechanism by which devotees experience spiritual realities may also 
produce the Eww! moment in theatre audiences. In the following three sections I argue that theatre-experience may be much like religious-experience, and not merely analogically, but qualitatively. First, I examine current theory related to the paradox of fiction. Several theories on this subject emphasize the role of imagination, variously understood, as the mechanism that produces real feelings for unreal objects. Implied in the theories of Michael Weston, Murray Smith, and Kendall Walton is the significance of socialization and conditioning in the operation of the imagination. Part two develops this implication through Hjalmar Sundén's role-theory, which argues that religious experience is a psychological operation relying on an individual's active identification with behavioral models valorized by specific religious traditions. The religious individual, according to Sundén, acts a role that anticipates and generates a religious experience. Finally, I correlate Sundén's theory of the religious individual who actively enters into a culturally determined role with the theatre-goer. The theatre-goer's experience develops from his or her own active role-playing - a playing that, like religious activity, fulfills its own anticipation.

\section{The Paradox of Fiction}

The philosophical argument about the paradox of fiction has swung in recent decades between an insistence on its inscrutability, the assertion that it's all in our heads, and the contention that there is no paradox in the first place. Colin Radford took up the paradox with fascination thirty years ago. "What is worrying," he writes, "is that we are moved by the death of Mercutio and we weep while knowing that no one has really died, that no young man has been cut off in the flower of his youth." And while Radford is never content with any of the several possible solutions he considers, he does identify a few points significant to the present discussion. Particularly relevant here is his contention that we cannot resolve the paradox by resorting to the argument of suspension-of-disbelief. ${ }^{6}$ We do not, Radford argues, ever not disbelieve. If we did suspend our disbelief, he reasons, we would be forced by the theatrical circumstances in which we, consequently, do believe to confront our own immediate relationship to the action. "Do we shout and try to get on the stage when ... we see that Tybalt is going to kill Mercutio? We do not."7 Our approach to a play and its content is always, and foremost, as an audience member at a play. ${ }^{8}$ Decades later, Radford concedes that the paradox continues to defy resolution. "[We] are irrational, inconsistent, and incoherent in being moved to pity for fictional characters," he concludes, "and we are nonetheless moved (of course)."9

The competing proposals attempting to resolve the paradox of fiction are consistently audience-centric. We seem to have satisfied ourselves that the work of fiction itself does not mandate an emotional response; or, if it does, that the paradox of an audience's emotion in the face of its consciousness of a work's 
fictionality does not arise. We also seem to accept that an author does not elicit by fiat an emotional response to or through her work. The audience's own activity, the way it meets and engages with fiction, recurs as a fundamental piece of aesthetic theory dealing with the paradox.

In recent work addressing the paradox of fiction, theorists such as Murray Smith and Noël Carroll have attempted to account for the persistence of our unbelief by challenging the premise that emotion always requires belief. Instead, they propose separate mental mechanisms through which an audience member supplements fiction's cognitive deficiency. Smith's mechanism is a particular kind of imagination, while Carroll's mechanism is a specific understanding of thought. Both theories indirectly, and perhaps unintentionally, elevate the role the audience itself plays in developing the condition in which real emotion arises in response to an apparent fiction.

Noël Carroll's approach to the paradox of fiction, for instance, hinges on thought, a mental faculty by which an audience elevates fiction to a cognitively legitimate status. In many cases, argues Carroll, thought is a sufficient cognitive component to produce legitimate feeling, and what he calls "unasserted propositions" - thoughts about the truth of which we maintain neutrality - if entertained imaginatively inspire feeling as if true propositions:

You do not need to believe that you are going to put the knife into your eye. Indeed, you know you are not going to do this. Yet merely entertaining the thought, or the propositional content of the thought (that I am putting this knife into my eye), can be sufficient for playing a role in causing a tremor of terror. For emotions may rest on thoughts and not merely upon beliefs. ${ }^{10}$

By insisting on the "unasserted" nature of the thought of a knife in one's eye, Carroll accounts for overt fiction that foments feeling while proposing a mechanism by which the fiction affects its audiences. ${ }^{11}$

Writing of the paradox as evident in audience reactions to cinema, Malcolm Turvey argues that the mental mechanism that Carroll postulates, upon which our emotional response to fiction rests, is unnecessary, even if it operates, as Carroll asserts, in certain circumstances. Turvey points out that if its principles are legitimate (and exclusively so), Carroll's thought theory suggests that thought or imagination alone, divorced from any particular medium, should be sufficient to inspire emotional reaction. If a mental mechanism mediates between an inadequate stimulus (such as the fictional content of a movie) and emotion by supplying the cognitive foundation for real feeling, a person ought to have the same reaction whether he "views the hypothetical fiction film or reads the shooting script upon which it is based." 12 Rather, says Turvey, the cinematic medium is sufficient in 
itself to affect us emotionally.

Following Turvey's critique, in Beyond Aesthetics Carroll offers a very useful adjustment in the form of a connection between the activity of authors and audiences. To account for the increased emotional efficacy of a finished film, as opposed to the screenplay which expresses the same fictional content, Carroll suggests that artistry directs and shapes the attention audiences give to the unasserted propositions or thoughts which arise from fictional content. Additionally, and most importantly, Carroll reasons, an audience reciprocates. The authors of fictions, Carroll tells us, offer us unasserted propositions which attract our attention, and then manipulate our attention through artistry so as to focus our anticipation as an emotional expectation, which we seek to sustain and satisfy in the work of fiction. ${ }^{13}$ Carroll sees that the kind of fictional objects which inspire feelings must be of a special, augmented sort. Under the scrutiny which an author sculpts, fictional objects, writes Carroll, "are lit, in a manner of speaking, in a special phenomenological glow . . . apposite to the emotional state we are in." 14 That is, Carroll suggests, we the audience invest fictional objects with the peculiar characteristic that enables them reflexively to draw emotional responses from us.

This element of Carroll's model is useful, identifying how an audience actively contributes to the way in which fictions affect them. If the development of an emotional reaction depends in its early stages on the entertainment of unasserted propositions, Carroll's theory seems to me a starting point for an examination of the audience member's life prior to the performance, rather than during it.

Thought theory's usefulness to discussions of emotional responses in more secular circumstances may be limited to understanding what we might call the "back story" of emotional responses to fiction. The "emotional state" of an audience member, upon which the "phenomenological glow" of Carroll's theory depends is, most often, well developed before the audience member's encounter with a fictional work, and is very often founded upon both asserted and unasserted propositions the audience member has already come to regard as equally true. The audience member's emotional state largely pre-exists her experience of a play, whether in the short term - say, an argument with a cab driver on the way to the theatre-or in the long term, such as the accumulated emotional and psychological weight of a life of poverty or ill-health, or the never-simple relationships of any never-typical family. The emotional content of those experiences for the audience member is largely shaped by both asserted and unasserted propositions the audience member has come to regard as equally true (or, at least, valid), including conventions of courtesy that govern driver-passenger interactions, economic theory, medical ethics, and religious doctrines that contextualize such things as family relationships. The audience member's emotional state may itself be a product resulting paradoxically from entertaining unasserted propositions; in this case, attention to the way an individual's emotional state phenomenologically lights a work of fiction is the 
beginning of the discussion, rather than the end.

In a response to Colin Radford, Michael Weston denies that a real paradox exists in the paradox of fiction, yet he nevertheless must construct an explanation of the phenomenon - an explanation which relies on recognizing how significant an audience member's own context is to the emotional viability of a fictional object. Citing social anthropologist Peter Winch, Weston notes that humans, as opposed to animals, not only live but have a "conception of life" which imbues things with particular values and develops meaningful associations between them. Consequently, Weston writes, "[the] importance of art to us is one way this concern to make sense of our lives appears. The possibility of our being moved by works of art must be made intelligible within the context of such a concern."15 Weston here offers Carroll's theory an important supplement. Each author notes that fictional objects develop emotional significance depending upon the part they play in an individual audience member's worldview, and, consequently, have a real emotional force to the same extent that the audience member's own "conception of life" (or worldview) is "real." The unasserted thought "Manhattan is made of pizza" produces no emotional response because we cannot to any degree maintain neutrality about its truth content, and cannot find a place for it in our worldview. However, "Astyanax is dead" can produce an emotional response in us; for, even though we remain non-neutral with respect to the truth of this specific thought, we nevertheless find a place in our worldview in which is assigned a value to children, their relationships with their mothers, and their untimely deaths, and this mechanism of location injects the thought of Astyanax's death with real emotional force. To some degree this is only factualism, at least insofar as the theory proceeds from a recognition of the basic truth that we do, generally, feel sad about dead children. But in his critique of thought theory, Weston articulates how our sociocultural environment provides the premise for the imaginative role-playing that others regard as essential to resolving the paradox.

Following Kendall Walton, Gregory Currie, Richard Wollheim, et al., in developing a theory of "imagining "from the inside'," Murray Smith offers an approach to the paradox of fiction that dwells more on an audience member's activity during the encounter with the work of fiction. ${ }^{16}$ For Smith, whose preferred medium, like Carroll's, is film, a spectator's emotional response to fiction comes from her capacity to imagine the experience of a character as presented by a work of fiction. Smith argues that, while watching a movie, audience members engage in a variety of simulative activities, imitating, in a way, what they can imagine is the emotional, affective, and autonomic experiences of the movie's characters. In this way, they imaginatively enter the movie, and their own responses to the movie's circumstances are the product of more or less successfully inhabiting in a makebelieve way one or another of the movie's characters (or, even, many of them at once). In Smith's terms, the undergraduate reaction in the case of the Eww!-Effect 
described above results from their vivid imagination of what it must be like to be Clindor, sucking fresh blood off the end of his finger.

The immediate point is that the Eww!-Effect may arise not from the audience entering into the play, but from the play spilling off the stage into the laps of the audience. Our groaning undergraduates do not respond in accord with Clindor'sthe character's - experience, which is characterized by barbaric ferocity rather than by squeamishness, but in accord with their own real-life aversion to the experience of someone else's fresh blood in their mouths. ${ }^{17}$ Which is to say that in the Eww! moment, they are not so much inside the play as the play is inside them. Smith partly accounts for this discrepancy by proposing different kinds of inside imagining. Acentral imagining, he asserts, involves "imagining the scenario 'outside' any [particular] character's perspective." "18 As an example of acentral imagining, Smith directs our attention to a scene from the film Homicide, in which we see a homicide investigator insult a murder victim and slur her ethnicity, unwittingly within earshot of the victim's granddaughter. Smith argues that our visceral reaction to this scene arises not from imagining the experience of a character in it, but from a much broader, more omniscient perspective than any one character in the scene could have.

Smith contends that acentral imagining is, like central imagining, a kind of imagining "from the inside" of the world of fiction. But the omniscience necessary to acentral imagining prevents us from inhabiting the inside of the fictional world, as much as it prevents us from inhabiting the experience of a particular character. ${ }^{19}$ Like the uncomfortable seats and velour curtains in a theatre, an omniscient or multi-perspective view reminds us perpetually of our position as viewers, outside the events of the fiction, so that whatever reactions an audience has as omniscient viewers are necessarily rooted in their own world of the theatre house. The play, or the movie, or the novel seems to produce emotional and other kinds of reactions to its content by infiltrating the audience's world, as much as the other way around.

Smith's approach lays more explicit emphasis than Carroll's on the active input of an audience. Like Carroll's "phenomenological glow," Smith's conception of the mechanism of "imagining," either centrally or acentrally, depends largely on the audience's own "back story," but focuses on the mental activity of the audience rather than on its emotional state. By promoting make-believe as the foundation of our paradoxical feelings for fiction, Kendall Walton takes an additional, crucial step, and one that unmistakably characterizes the audience experience as analogous (at least) to religious experience.

Walton draws our attention to the imaginative playing of children and asserts, "We appreciators [of fiction] also participate in games of make-believe." ${ }^{20}$ The salient element of Walton's theory is "personality," which "activates psychological mechanisms" in the face of fiction so as to bring on "genuine distress." Walton describes at some length a scenario in which a person goes caving: crouching, 
crawling, and eventually wriggling deep into an ever-narrowing and lightless tunnel until the passageway is so attenuated as to prevent turning of any sort-and then the caver's lamp fails. Following this story, Walton concludes, "My imagining of the spelunking expedition taps into my actual personality and character. This, I am sure, is why it affects me as it does. It is because of my (dispositional) claustrophobia that I find it distressing to imagine slithering on my belly through the cramped passages of a cave." ${ }^{21}$ An individual, continues Walton, awakes her dispositional nature through an active process of make-believe, or, more philosophically stated, through mental simulation. The claustrophobic anxiety paradoxically felt in the comfort of an easy chair on the back patio arises naturally, and in a real way (or, at least, a manner that is really felt) from the way her active, mental simulation of the caving scenario awakens, directs, and focuses her own inherent phobia of dark, oppressive spaces. The real feeling, such as it is, is not created by the scenario, but "is a standing (or dispositional) condition which I had all along and which is merely activated and revealed by my imaginative experience." 22

Walton's caving story may evoke nightmares of Method exercises, if not of caves. Whether via the Method or otherwise, entering into such an imaginative experience is often a basic, readily recognized, activity of "acting" as conceived in the $20^{\text {th }}$-century West. I am not, however, seeking here a recapitulation of acting, per $s e$. Rather, I am reaching for an understanding of audiencing, especially to suggest that there might not be a reason to distinguish too clearly between the two. The feeling audience member, if we follow Walton, et al., does not passively absorb the content of the fiction - content which then works inside the audience member to produce feeling - but, to the extent that her real-world experience allows, opens herself to the world of the fiction, assuming, in an active way not unlike an actor, a role that corresponds with and facilitates the course of the fiction.

\section{Role-Theory of Religious Experience}

Religious experience is a phenomenon similarly dependent on a particular cultural worldview and the degree to which an individual plays within that worldview. Because of the way in which religious experience may be said to arise from the manner in which individuals order and value what they encounter, often with open disregard for their apparent, physical circumstances, religious experience provides a very useful model for the kind of theatrical experience in which emotional response to fiction arises. Proceeding from William James's premise that religious experience is fundamentally irrational, we can identify a similar paradox in theatrical experience: whereas with fiction we wonder how we can feel while recognizing pretense, we might wonder, at least from the point of view of an empirical theory of knowledge, how religious experience is at all possible.

One way of approaching the paradox of religious experience is role-theory, a psychological theory developed by Hjalmar Sundén, once a professor of the 
Psychology of Religion at Uppsala University in Sweden. Role-theory understands religious experience as a combination of social and environmental forces with an individual's own propensity for role playing. The theory which Sundén developed beginning in the late 1950s is not only theatrical in its own terminology and conception, but provides a way of productively reconsidering what theatre audiences undergo. Refocused on theatrical experience itself, Sundén's theory offers a compelling approach to the paradox of fiction by describing in psychological terms the way in which audience members actively contribute to their experience of art.

Sundén's theory, in the first place, rests on the same premise as Weston's argument concerning the paradox of fiction, which is that individuals inevitably seek out ways of making sense of their lives. Weston postulates that this search for sense or meaning accounts for our emotional experience of fiction. Similarly, Sundén suggests that an individual's search for meaning accounts for his or her religious experience, and he conceives a specific psychological mechanism by which the individual proceeds from search to experience.

According to Sundén's role theory, individuals attain to religious experiences by way of preparation and participation. Myths - broadly understood as history, legend, scripture, theology, philosophy, and so forth-repeated in the context of religious life provide models and patterns of meaning that individuals may adopt for themselves by identifying with the roles in the myths. As a consequence of this role-playing, individuals prime themselves to experience what their mythical prototypes experience. "If one has therefore learned the narrative [myth] in question," writes Nils Holm, "one is in possession of a set for specific religious experience. One then carries a latent psychological propensity to experience the world in a religious manner." The myth, then, provides a meaning-generating structure for an individual's experience of life. "If, from the individual's own perspective," continues Holm, "there is a similarity between his own situation and a particular narrative in the holy tradition, the myth, a restructuring phenomenon can occur in that person, so that the mythological reality also becomes reality for the individual in question." 23 Given effective stimuli-present circumstances which seem to correspond with the circumstances of mythic paradigms - the individual who has incorporated those paradigms into his or her worldview responds in the character of an appropriate model, conflating his or her immediate experience with the experience of the mythic role, such that the individual and the role blend.

The effect of the process Sundén proposes is that the individual upon whom such a pattern works comes to order his or her perception of reality in a particular way, and not, necessarily, in accord with an empirical view. What is 'real' to the religious individual is that which corresponds to and reinforces the mythic models, as well as the individual's correspondence to the models. At some length, Sundén offers the example of Max Dauthendey, a German national interned by the Dutch on 
Java at the start of World War I, in whose Bible was found the following note:

Tosari-Saturday June 30, 1917. In the morning this day when I read the Psalms of David numbers 50 and 60 and insight flashed upon me. I understood that there is a personal God. Three weeks before my fiftieth anniversary I got this revelation. - What a splendid certitude about the goal entered today into my heart, into my spirit, into my body. - God lives, He is a person, and everything lives through Him. ${ }^{24}$

With reference to Dauthendey's journal, Sundén proceeds to interpret the experience in the following way:

From his diary we learn that Dauthendey was very anxious about his native country, which on June 30th, 1917 had been engaged in a great war for three years. When he came to Psalm 60, which in the Luther-Bible has the heading Gebet in Kriegszeiten (or "prayer in times of war"), he found words that he could easily make his own. Doing so, the reading may have changed into a real prayer.... Dauthendey had in fact been in real trouble. He could therefore experience God's "I will come to your rescue" statement as addressed especially to him, and the words he found in Psalm 60 made it easy for him to take the role of the praying man who approached God in this way. What then happened seems to be that God ... suddenly enters his perceptual field as a personal presence that gives it new structure. ${ }^{25}$

Dauthendey, then, serves as an example of the way an individual, through his perception of a similarity of circumstances (war), identifies himself with a sanctified model (the Psalmist), and restructures his worldview so as to accommodate the correspondence between himself and the mythic model. The Psalmist experienced a revelation of God, and Dauthendey, by entering into the role of the Psalmist, does, too.

We must note, however, that Dauthendey does not come to think of himself as the Psalmist. His perceptual field does not change in such a way that he loses his sense of distance between himself and the writer of the Psalms. For Dauthendey, the Psalmist is still dead, his written words still on the page (even if sacred), the Biblical moment still an event removed by history from Dauthendey's immediate circumstances. Dauthendey's experience, then, coexists with a clear and conscious awareness that he has not entered into the Psalmist's relationship with God in any literal way; rather, the experience he has through an association with the Psalmist 
is distinctly his own.

The individual's anticipation of a particular experience associated with an adopted role tunes the individual to find that experience in his or her own circumstances. This kind of anticipation fulfillment operates in secular as well as spiritual ways. Holm summarizes a decidedly secular example, frequently cited by Sundén:

In Northern Sweden the criminal police received knowledge of a criminal league from Finland which was wreaking havoc on the Swedish coast. A search party set out. It was discovered that a wrecked cottage had been broken into and that the thieves had stolen a couple of rifles, together with ammunition. A rowing boat had also disappeared. The latter was discovered on an island. Therefore the thieves were also probably present on the island. The search party disembarked and moved forward over the open countryside. Suddenly the commander leapt behind a rock for shelter. He had seen a man pointing a gun at him. He waited for the whistle of bullets, but nothing happened. Finally, he got up and searched carefully over the terrain. He found a beer-bottle lying on the ground, with the neck pointed toward him, and this shape corresponded to an element in the preparedness that the commander had built up: the gun barrel which he had been expecting to see. ${ }^{26}$

Here, the commander's training as a police officer, his experience in the profession, the circumstances of this case, cooperated to fuel a specific anticipation that his immediate environment easily fulfilled. And we find in this particular case something not unlike the Eww!-Effect, as the commander reacted to a beer bottle as though it had been a rifle.

Of course, this commander's substantive fear for his own, real life, such as theatrical audience members never experience, contributed in a significant way to a misperception that borders on delusion; nor was the commander here simultaneously faced with explicit frames of fabrication, such as theatrical audiences generally face. This example only draws our attention to the important role that anticipation plays in Sundén's theory. If applied to theatre and audiences simply to say that, by entering roles which correspond with stage characters, audience members anticipate stage action in such a way that finding some means of fulfilling those expectations is almost inevitable, role theory does not contribute to the discussion of the paradox of fiction beyond the conventional understanding of "suspension of disbelief."

But by further distinguishing between "role-taking" and "role-adopting," Sundén suggests that audiences do something more functional than merely 
"suspend disbelief," something that better accounts for audience experiences that often exceed the possibilities of Coleridge's phrase. For Sundén, not only does the religious individual take the role of a counterpart in myth (thus anticipating the role's experience), but the same individual also adopts the role of God, which is to say that the individual incorporates the perspective of that figure to which is attributed the power to fulfill the expectations of the mythic role. This understanding of the dual aspects of roles develops from the interactionist model of sociology and psychology which reasons that identity is partly constructed through an individual's understanding of how others perceive him or her. According to this model, an individual role-plays especially as a mechanism of self-examination. "Through role-play, the child for example is able to enter into the experience of how others perceive it," Holm explains. "The child can be both child and mother in one and the same game. By means of such games, the child learns to internalize other people's evaluations of itself. The child, in other words, acquires its conscious knowledge of generalized others." ${ }^{27}$ What this means for Sundén's theory is that dual perceptions characterize religious experience:

[The] individual takes the role of the human party in a mythical role play, and simultaneously adopts God's role, which unconsciously structures perception so that what happens around the individual is actually experienced as the action of God. For a brief instant, the person can quite concretely experience the action of God. A phase shift has taken place, and the individual field of perception has become structured by a mythical role. ${ }^{28}$

In this way, the individual's perception of the ontological reality of God is partly a consequence of inhabiting God's point-of-view with respect to the mythic model at the same time as inhabiting the mythic model itself, which the individual has identified with his or her situation. Wikström describes the process in this way:

[When] someone takes the role of a human in a text, he adopts or anticipates the role of 'the Other.' He will expect that God will act towards him in his actual situation in the same manner as God acted towards the figure he identified with in the text. $\ldots$ When the religious frame of reference is active, there is a readiness to perceive reality in an alternative way. ${ }^{29}$

Not only does the police commander take the role of "target" while searching the countryside, but he adopts the role of "sniper," a point of view which restructures his perception. Not only does Dauthendey take the role of the Psalmist, he also adopts the role of God in response to his own dire circumstances and pleas, and in 
doing so reconfigures his reality.

\section{The Role-Playing Audience}

When applied to the paradox of fiction as manifest in theatre, role theory may suggest that what is explicit in religious practice may be unavoidably implicit in theatre traditions. We can read dramatic literature as scripturally paradigmatic, and fictional characters - dramatic characters - as enjoying an ontological status similar to the roles of Sundén's theory. In the same way that an individual facing a difficult surgery can experience the comforting presence of God by identifying with the biblical Isaac, a theatre-goer can experience the displeasure of tasting blood by identifying with the Calderonian Clindor. An audience member takes and adopts roles relevant to stage action in a way that is similar to the way subjects of religious experience take and adopt paradigmatic and divine roles.

That is not to say that theatre-goers "believe" in theatrical characters in the way religious believers believe in the figures of scripture. Certainly, for the believer, the biblical Abraham is more real than Mercutio. But historical reality is not the issue here, since, historically real or not, the figures of scriptural texts are not present. The act of reading the Bible itself does not bring Abraham to immediate and tangible life in the presence of the reader, regardless of his or her position with regard to Abraham's historicity. For the reader, Abraham is absent, removed from perception, and only appears to the devotee in (theatrical) representation. As Sundén conceives it, a religious experience that arises from reading Genesis is not an experience of Abraham's historical reality, but an experience of God through the narrative model of Abraham's experience of God, as available solely through the text and the cultural tradition of the text. Consequently, since none of them is any more present than another in the reader's or the spectator's experience, Abraham and Mercutio (and Krishna and Blanche) appear to us similarly, and we can interpret each as a facilitator of Sundén's theoretical process. When we do, we see that the audience may similarly identify with Mercutio and his dramatic circumstances so as to associate those circumstances with the audience member's own circumstances.

Taking Mercutio's role, the audience member enters into a condition of anticipation, expecting the pattern to come to a conclusion and associating the pattern with his or her own circumstances in such a way as to develop meaning both for the stage action and for his or her personal situation. Simultaneously, the audience member adopts a role which the pattern suggests stands in a transcendent position enabling it to fulfill the pattern's expectations. Given the audience member's consciousness of the fabrication of the dramatic circumstances, this role inevitably emerges as the forces of the playhouse itself, embodied in the playwright, the director, the actors - those involved in the artistry of the production-so that the audience member's emotional experience arises, as does Sundén's religious 
experience, from the audience member's dual identity as a subject of circumstances (a Mercutio type) and as a creator of circumstances (an artist). By integrating the model with a sense of power over the model, the audience member unifies the fictional world and his or her empirical world so as to undergo a "phase shift" in which "the individual field of perception has become structured by a mythical role." 30 At this point, the reality of the play and the reality of the theatre are blended. Insofar as the audience member believes his or her own living circumstances to be real, when those circumstances mingle with the circumstances of the play, there is, in fact, a cognitive basis for the audience member's tearful experience, just as religious experience develops from the blending of empirical and spiritual realities. ${ }^{31}$ Art and spirituality occupy similar positions in both types of experience, as the individual subject actively constructs (even if only on a temporary basis) a legitimate understanding of what is happening in his or her field of perception.

Sundén's role theory gives us a sense of how actively an audience contributes to a theatrical production. The individual comes to religious experience as the object of cultural conditioning, to be sure, but ultimately only as a consequence of his or her propensity for playing with - and in - that conditioning. Certain activities, such as scripture reading, prayer, and ritual, explicitly assist the individual's play and provide reflexive reinforcement for the individual's sense of a role's legitimacy, so as to facilitate the phase shift by which the individual, as the protagonist, plays out a mythic pattern. Theatre (usually) does not offer such explicit assistance to audience members. But theatre audiences similarly approach productions from a position of cultural conditioning (to which theatre itself contributes), and, in their uncomfortable seats beneath the exit signs, enter into play which combines both the world inside the production and the world of the theatre. In this way, theatrical experience is religious experience. Both seem to defy reason, and both develop through the same mechanism, which is the audience's creative activity. Emotional experience of theatre, the kind which seems to be at odds with a production's explicit fabrication, is, thus, less the consequence of the production itself-its realism, style, expression, the peculiar power of its artistry-than it is the result of the production's harmony with an individual audience member's worldview and that individual's peculiar propensity for play.

Generally speaking, Western theories of dramatic performance, at least of the last century, expect that the actor generates (by skill, training, talent, inspiration, or whatever means are at his or her disposal) the world of the play, and dynamically draws the audience into that world. ${ }^{32}$ The degree to which Olivier is Hamlet is a function of the deportment of Olivier. The Stanislavski System developed precisely to equip actors to assume this responsibility. And not only do the so-called realistic forms of Western theatre rely on the actor as their means of cogency. Artaud, Brecht, Grotowski, Bogart, et al., all put actors at the center of their theories of performance. The degree to which Weigel's scream directs our attention to the crime of human 
inconstancy should be understood as a function of Weigel's own peculiar talent. The dependency of theatrical performance on actors is not unreasonable. Since the actor is the medium by which dramatic narrative generally occurs, she therefore seems the natural instrument to vivify that narrative.

However, like the Stanislavskian actor who builds a character on a foundation of her own experience and feeling, the audience member also arrives at an emotional experience of a play by way of her own experience and feeling. Like a religious devotee, the feeling theatre-goer, when she intuits a space on stage in which she fits, actively constructs a relationship to the characters and the action of the play that can itself fulfill intentions (the play's and her own). Her experience follows as the consequence of a kind of devotion: the culmination of a pattern beginning before the curtain rises - indeed, before the patron arrives at the theatre - a pattern learned, practiced, and exercised over time, and reinforced by the similarly lived patterns of patrons around her. Feeling, then, for staged fiction in the face of the multitudinous frames that indicate fiction, demonstrates just how actively an audience member works during a performance. As much as the actors themselves, the feeling audience member plays a part in the production and contributes as a player to the production's effect.

\section{Notes}

1. A production of Tony Kushner's adaptation of Corneille's The Illusion by the Theatre Program at Georgia College and State University in the Spring, 2004, directed by Marlene Johnson. 63.

2. William James, The Varieties of Religious Experience (New York: Simon \& Schuster, 1997)

3. The experience James relates here, as he acknowledges, "does not connect itself with the religious sphere." However, James includes it as representative of a kind of transcendent experience, which "may upon occasion" be identified by subjects as religious. I include this manifestation of the experience on account of its close correspondence to the Eww!-Effect of the Kushner production. See James 64.

4. 60

5. Colin Radford, Michael Weston, "How Can We Be Moved by the Fate of Anna Karenina?" Proceedings of the Aristotelian Society, Supplementary Volume 49 (1975): 71. In this article, Radford and Weston respond separately to the question posed in the title.

6. At least, not suspension-of-disbelief as the phrase is colloquially employed. Coleridge, who coined the phrase, did not argue we could completely disbelieve, but wrote we are "never absolutely deluded - or anything like it." See Bernard Dukore, Dramatic Theory and Criticism: Greeks to Grotowski (Boston: Heinle, 1974) 588.

7. Radford, Weston, "Anna Karenina" 71.

8. This is an important point to keep in mind as a link between theatrical experience and religious experience, in which, whatever the degree of reality ascribed to a spiritual world, distinctions between material present and spiritual present are consciously maintained. Just as we don't jump to the stage to prevent Mercutio's death, the religious Christian, for example, knows even while he worships that he cannot (and, perhaps, should not) interfere with the crucifixion. That the Christian recognizes Jesus as a historical reality and Mercutio as a character of fiction is precisely the issue. The audience member is affected in a real way by what happens to Mercutio, and it may be that the psychological mechanism by which that happens is similar to the way in which Jesus's passion, which is not happening in an immediate, temporal way, affects Christians.

9. Colin Radford, "Fiction, Pity, Fear, and Jealousy," The Journal of Aesthetics and Art Criticism 53 (1995): 71-75. 
10. Noël Carroll, Beyond Aesthetics (New York: Cambridge U P, 2001) 234.

11. In addition to Turvey's various objections to Carroll's theory, we need not accept the proposition that the shudder one experiences at imagining a knife in one's eye is the same phenomenon as shedding a tear over Mercutio's death. Emotion is not necessarily the same as physical revulsion.

In any case, we might reconsider whether the neutrality required by Carroll's "unasserted proposition" is possible. It is impossible to be neutral about the "truth value" of the proposition "Manhattan Island is made of pizza," which Carroll offers as an illustration. In fact, while one can imagine that Manhattan is made of pizza, one categorically cannot be neutral about this proposition's truth value, any more than we can suspend our disbelief about it. Similarly, we cannot be neutral with regard to Mercutio's stage death, since, however vividly we entertain the thought, we recognize clearly the kind of death involved (or, if we did not, as Radford suggests, we would jump on stage and try to interfere).

12. Malcolm Turvey, "Seeing Theory: On Perception and Emotional Response in Current Film Theory," Film Theory and Philosophy, eds. Richard Allen and Murray Smith (Oxford: Clarendon, 1997) 434.

13. Carroll 235.

14. 235 .

15. Radford, Weston, “Anna Karenina” 92.

16. See especially chapter three of Murray Smith's Engaging Characters: Fiction, Emotion, and the Cinema (Oxford: Clarendon P, 1995).

17. We might suppose that the Eww! elicited by the action here also arises from the undergraduates' aversion to someone sucking on their own freshly spilled blood. In either case, the students respond not as though inhabiting Clindor's point of view, but as though they themselves were experiencing the circumstances of the play's events.

18. Murray Smith, "Imagining from the Inside," Film Theory and Philosophy, eds. Richard Allen and Murray Smith (Oxford: Clarendon P, 1997) 415.

19. "In either minor or major ways," writes Smith, "fictions always break absolute alignment between character and viewer," 424.

20. Kendall Walton, "Spelunking, Simulation, and Slime," Emotion and the Arts, eds. Mette Hjort and Sue Laver (New York: Oxford U P, 1997) 38.

21. 39.

22. 42 .

23. Nils G. Holm, "Sundén's Role Theory and Glossolalia," Journal for the Scientific Study of Religion 26 (1987): 384.

24. Quoted in Hjalmar Sundén, "Saint Augustine and the Psalter in the Light of RolePsychology”Journal for the Scientific Study of Religion 26.3 (1987): 375.

25. 376 .

26. Nils G. Holm, "Role Theory and Religious Experience," in Handbook of Religious Experience, ed. Ralph W. Hood, Jr. (Birmingham: Religious Education P, 1995) 407-8.

27. 401.

28. 409.

29. Owe Wikström, “Attribution, Roles and Religion: A Theoretical Analysis of Sundén's Role Theory of Religion and the Attributional Approach to Religious Experience," Journal for the Scientific Study of Religion 26 (1987): 393.

30. Holm, "Role Theory" 409.

31. Role theory thus accounts for a cognitive state of belief, if such a state is, indeed, necessary to resolve the paradox of fiction.

32. Euro-American theatre is not alone in this regard. Various performance forms in Japan, China, Africa, South America, and particularly India, equally depend upon their actors' talents and skills. The present argument is concerned with the emotional experience of Western performance in the Stanislavskian tradition. Arguments regarding the applicability of this theory to other types of theatre fall outside the scope of this writing. 